\title{
Traçando vidas de brasileiros distintos com escrupulosa exatidão: biografia, erudição e escrita da história na Revista do Instituto Histórico e Geográfico Brasileiro (1839-1850)
}

\author{
Maria da Glória de Oliveira*
}

Resumo: O artigo pretende refletir acerca da publicação de textos biográficos na Revista do Instituto Histórico e Geográfico Brasileiro entre 1839 e 1850. A hipótese a ser considerada é a de que a biografia dos brasileiros ilustres constituiu-se em um gênero de escrita vinculado ao lugar de sua produção e submetido aos procedimentos e regras de uma operação historiográfica.

Palavras-chave: escrita da história, biografia, Instituto Histórico e Geográfico Brasileiro

\section{Introdução}

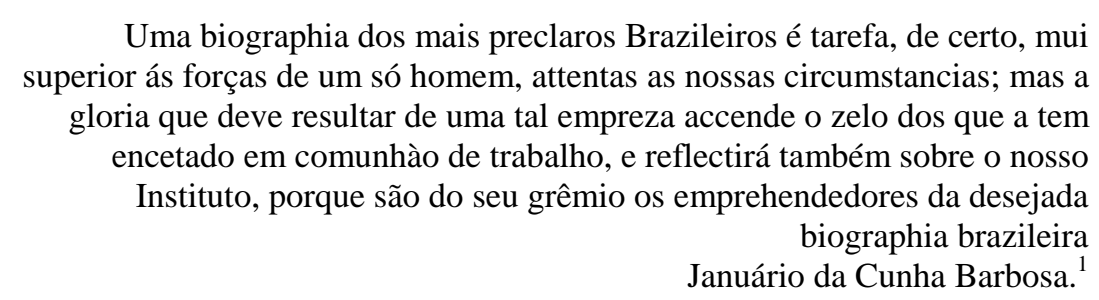

As proposições acerca da escrita de biografias de brasileiros ilustres, enunciadas enfaticamente pelo cônego Januário da Cunha Barbosa (1780-1846) em 25 de novembro de 1838, adquiririam contornos concretos com a criação de uma seção específica na Revista Trimestral do Instituto Histórico e Geográfico Brasileiro. Em seu segundo número, editado em julho de 1839, o título Biographia dos Brasileiros Distinctos por Lettras, Armas, Virtudes, Etc. aparece pela primeira vez e é dedicado à vida do poeta José Basílio da Gama. ${ }^{2}$ A circunscrição deste espaço, contudo, não esgota o corpus biográfico produzido pelos sócios da instituição. Até 1899 podem ser contabilizados 154 trabalhos sob a rubrica de biografia ou de apontamentos biográficos (ver quadro 1). 3

Com um critério de quantificação distinto, Lúcia Maria Paschoal Guimarães identificou 167 biografias e necrológicos, que corresponderiam a 30\% dos impressos na 
Revista no período. ${ }^{4}$ Entretanto, a autora descartou a relevância dessas produções, entendendo que não serviriam como indicadores significativos da atividade historiográfica dos membros do IHGB, por se tratar, muitas vezes, de transcrições de obras de autores não pertencentes aos quadros da instituição. ${ }^{5}$

A dificuldade decorrente deste tipo de argumento está no fato de que, com ele, fica subentendida a possibilidade de identificação de uma historiografia supostamente representativa do Instituto. Em contrapartida, verifica-se que os trabalhos publicados na Revista, inventariados em seu conjunto, possuem diversificadas denominações, entre as quais aparecem, além das já citadas biografias e necrológios, elogios históricos, memórias, relatos, crônicas, anais, dissertações, corografias e tratados. Toda tentativa de classificação defronta-se, portanto, com o problema da heterogeneidade e irredutibilidade desses textos a uma categoria genérica de composição. De imediato, seria mais conveniente pensar em variações nos usos do gênero historiográfico, evidenciadas nas diferentes organizações discursivas de que se servem os letrados do IHGB no século XIX. ${ }^{6}$ Nesse momento, a produção do conhecimento histórico encontra-se em vias de institucionalização como discurso dotado de regras próprias de construção e validação. Entre os efeitos da tendência à autonomização disciplinar, estaria a própria fundação do Instituto e, com ela, o surgimento do debate sobre como deveria ser escrita a história nacional, que se prolonga por todo o período oitocentista. ${ }^{7}$

Outro ponto a considerar é o de que as práticas de pesquisa histórica e de elaboração do discurso historiográfico, porquanto mediadas por convenções estabelecidas no interior dos lugares de produção de saber, sempre foram condicionadas pelas escolhas dos historiadores. Longe de serem fortuitas, essas escolhas dizem respeito à capacidade de organizar os fatos segundo modalidades discursivas diversas e, por conseguinte, relacionam-se à busca de modelos de inteligibilidade e atribuição de sentido para as evidências históricas. ${ }^{8}$ Assim, nas primeiras décadas de existência do IHGB percebe-se a publicação massiva de memórias históricas que, de modo geral, consistiam em compilações documentais e notícias descritivas acerca das províncias do Império. O uso recorrente dessa forma de registro historiográfico corresponde, sem dúvida, à concepção cumulativa de construção do conhecimento histórico que pressupunha o trabalho de ordenação e arquivamento de vestígios do passado e constituía-se, portanto, em precondição para a escrita de uma história "geral” do Brasil. ${ }^{9}$ De acordo com esta idéia, Joaquim Manoel de Macedo (1820-1882), primeiro secretário interino em 1852, definia a “collecção" de Revistas do IHGB como um “coffre 
precioso", onde se imprimiam "interessantes memórias e preciosos manuscriptos", visando o conhecimento dos feitos dos nossos antepassados e a escrita da história pátria. $^{10}$

Se o levantamento dos índices de matérias publicadas na Revista do IHGB entre 1839 e 1899 demonstra a presença considerável de memórias e notícias históricas, também aponta para a profusão e a regularidade com que os escritos biográficos foram elaborados pelos seus sócios. Mais do que gênero exaltado de maneira enfática pelo primeiro secretário em seu discurso de fundação, a biografia incorporava-se ao projeto de escrita da história nacional. ${ }^{11}$ Mesmo que alguns desses textos aparecessem identificados como extratos ou transcrições de outras obras - como, por exemplo, da Bibliotheca Lusitana de Diogo Barboza Machado -, não dispensavam a inclusão de comentários e, muitas vezes, correções e adendos por meio de notas de pé de página a cargo do redator da Revista.

Como autores das notícias identificam-se os nomes de alguns dos letrados mais destacados do Império como o próprio Cunha Barbosa, João Manuel Pereira da Silva (1817-1898), Joaquim Norberto de Sousa Silva (1820-1891), Manuel Duarte Moreira de Azevedo (1832-1903) e o cônego Joaquim Caetano Fernandes Pinheiro (1825-1876). Francisco Adolfo de Varnhagen (1816-1878), autor da História Geral do Brasil, foi o que colaborou com o maior número de textos incluídos na seção entre 1840 e 1867 foram 29 no total.

Neste artigo, trato da escrita de biografias pela primeira geração de sócios do IHGB, propondo algumas reflexões acerca dos usos do gênero biográfico e as suas relações com a operação historiográfica no âmbito dessa instituição durante o século XIX. A idéia é estudar as biografias como um corpus de textos publicados no espaço da Revista, ou, ainda, como uma modalidade de escrita que, embora fosse dotada de convenções próprias, submetia-se aos procedimentos da crítica histórica, incorporandose às tarefas do historiador. Não se trata, portanto, de analisá-las como peças isoladas, nem tampouco de reduzi-las à sua relação singular com um determinado autor.

Cabe ainda ressaltar que não pressuponho história e biografia como gêneros puros ou inalteráveis em suas disposições, mas como formas discursivas historicamente condicionadas por diferentes práticas e tradições letradas. ${ }^{12}$ Como bem ressaltou Arnaldo Momigliano, a despeito da notória diferenciação que, desde os gregos, sempre existiu entre ambas, a relação entre os dois modos de escrita variou segundo as épocas e os lugares, o que implica considerar, ao mesmo tempo, o que os separa e o que os 
aproxima. ${ }^{13}$ Desse modo, o que convém perguntar é o que, de fato, tornou possível o contato entre a biografia e a história no Brasil no século XIX. Além disso, também é importante que se examine a biografia em suas relações com as práticas de erudição e com outros gêneros discursivos como os panegíricos e os elogios históricos.

$\mathrm{Na}$ tentativa de buscar algumas respostas a estas questões, em um primeiro momento, analiso as condições sob as quais a escrita das vidas de brasileiros ilustres justifica-se com base na fórmula da historia magistra - argumento que orientaria o projeto historiográfico do IHGB, muitas décadas após a sua fundação. Em seguida, investigo os usos da tópica das armas e letras, presente no título da seção, como elemento que define critérios de distinção e fixa atributos da exemplaridade dos biografados no panteon de papel erigido pela Revista ao longo do século XIX. ${ }^{14} \mathrm{E}$, por fim, procuro identificar como a elaboração de notícias biográficas foi incorporada às tarefas do historiador e submetida aos procedimentos da pesquisa e da crítica históricas.

\section{Das utilidades magisteriais da história}

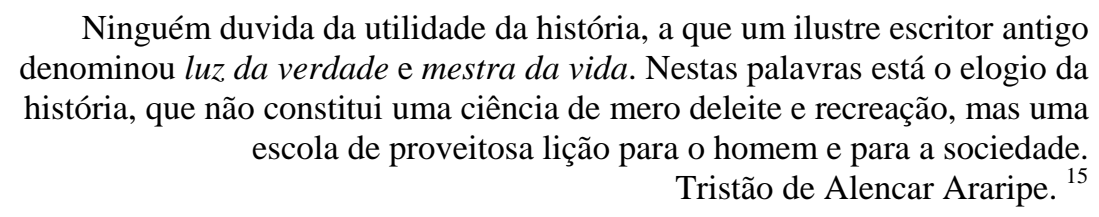

As considerações acima, publicadas em 1894, caracterizavam a concepção que se manteve predominante entre os letrados do IHGB acerca dos modos pelos quais se deveria escrever a história nacional. ${ }^{16}$ Em seu discurso, Tristão de Alencar Araripe (1848-1911) atribuía à história a função de explicar o presente e esclarecer o futuro da pátria. ${ }^{17}$ Ao discorrer sobre o modo como esta deveria ser escrita, Araripe enfatizava que, ao historiador, caberia “dezenhar a figura respeitável dos nossos homens beneméritos”, oferecendo-os à imitação do leitor como grandes modelos de patriotismo.

Será um dos sagrados deveres do historiador brazileiro aprezentar á veneração dos posteros a memória dos varões beneméritos, que engrandeceram essa pátria com proezas generozas, invenções úteis, e obras excelentes. ${ }^{18}$ 
Neste caso, a referência do conselheiro não poderia ser outra senão Plutarco: como o autor grego “desenhara” os homens célebres da Antigüidade, o historiador brasileiro deveria “pintar” os nossos grandes cidadãos, após examinar “com escrupulosa diligência a verdade”, de forma que suscitasse “patriotas sinceros e verdadeiros”. 19

Na reafirmação do topos da historia magistra vitae firmava-se o princípio de justificação e de orientação da investigação histórica. Na definição ciceroniana, cuja formulação original vinculava-se à retórica, atribuía-se ao orador a capacidade de “conferir imortalidade à vida das histórias instrutivas, de tornar perene o seu tesouro de experiência”. ${ }^{20}$ A tarefa suprema da história, concebida como opus oratorium maxime, estaria presumidamente orientada à práxis e, portanto, ao tempo presente em que estariam imersos o orador e o seu público. Ele se serve da história "como coleção de exemplos - plena exemplorum est historia - para instruir mediante eles”. ${ }^{21}$ Acerca desse aspecto, François Hartog observa que o uso dos exempla - através do relato da vida dos homens célebres - podia ser o recurso com o qual os oradores antigos narravam a história das cidades, reportando-se ao passado para fornecer modelos à imitação dos cidadãos. Na composição de seus discursos, o exemplo corresponde ao momento da argumentatio ou probatio, sendo usado, portanto, como um instrumento de persuasão. ${ }^{22}$

Dentro do IHGB, ao longo do século XIX, o tema da história fornecedora de exemplos a serem imitados acompanhava o regime de historicidade no qual o acento referencial no passado constituía-se em razão explicativa do presente e perspectiva orientadora para o futuro. ${ }^{23}$ Com base no lugar-comum ciceroniano, Alencar Araripe incitava os historiadores do Brasil a que cumprissem o "sagrado" dever de memória para com os seus compatriotas notáveis. Nesse contexto, a evocação de um cânone da tradição clássica não representava uma novidade. No curso de quase quarenta anos de atividade do Instituto, o nome de Plutarco continuava a cumprir a função de argumento de autoridade para um projeto histórico-biográfico, cuja primeira formulação pode ser identificada no momento de sua inauguração:

Na vida dos grandes homens aprende-se a conhecer as applicações da honra, a apreciar a gloria e a affrontar os perigos ... O livro de Plutarco é uma excellente escola do homem, porque offerece em todos os gêneros os mais nobres exemplos de magnanimidade; ahi se encontra descoberta toda a Antigüidade. ${ }^{24}$

Lido na sessão inaugural do IHGB, em 1838, o discurso de Januário da Cunha Barbosa representou a primeira tentativa de demarcação das diretrizes teórico- 
epistemológicas para a elaboração da história nacional. ${ }^{25} \mathrm{O}$ caráter paradigmático das suas formulações estaria precisamente nos balizamentos metodológicos dirigidos àqueles que, doravante, pretendessem elaborar a história e a geografia do Brasil.

A inauguração do Instituto Histórico e Geográfico no Rio de Janeiro possuía, de imediato, uma razão de ordem política:

Não se compadecia já com o gênio brasileiro, sempre zeloso da glória da patria, deixar por mais tempo em esquecimento os factos notáveis da sua historia, acontecidos em diversos pontos do Imperio, sem duvida ainda não bem consignados. ${ }^{26}$

Os sócios da nova agremiação, movidos pelo "patriotismo e amor das lettras”, deveriam coligir e organizar os elementos para os estudos históricos e geográficos nacionais, que se encontravam dispersos nas províncias. A proposição de transformar o IHGB em centro autorizado para a produção de um discurso sobre o Brasil reforça o caráter político do projeto historiográfico que então se formulava. Este aspecto se torna evidente na própria estratégia de fundação da instituição para cuja sede, na capital do Império, deveria convergir a soma dos conhecimentos acumulados sobre a nação. Concebido de forma ampla, o projeto da história nacional articulava-se, de fato, ao projeto de centralização política, vitorioso em meados do século XIX. ${ }^{27}$ Uma atribuição não menos importante relacionava-se à “purificação dos erros e inexatidões” do que se escrevera sobre o Brasil até aquele momento: era necessário que não se deixasse mais a cargo “do gênio especulador dos estrangeiros o escrever a nossa história”. ${ }^{28}$

A historiografia a ser forjada dentro do IHGB propunha-se eternizar os fatos memoráveis da pátria, bem como salvá-los do esquecimento - operações indissociáveis da fórmula que atribuía à história as funções de testemunha dos tempos, luz da verdade e escola da vida. ${ }^{29}$ Tal concepção de história tornar-se-á manifesta na epígrafe estampada na capa da Revista desde o seu primeiro número: Hoc facit, ut longos durent bene gesta per annos; et possint serâ posteritate frui ("Com isto, faz que as boas ações durem por longos anos e possam fruir de uma posteridade prolongada”). ${ }^{30}$

A vocação pedagógica do conhecimento do passado aparece, portanto, como o argumento que confere legitimidade e força persuasiva às primeiras proposições acerca da escrita da nossa história, entre elas a da produção de biografias. "E será pouco arrancar ao esquecimento, em que jazem sepultados, os nomes e feitos de tantos illustres Brasileiros, que honraram a patria por suas lettras e por seus diversos e brilhantes serviços?”31 Uma das vantagens da história estava em sua capacidade de livrar da 
obscuridade e restituir à memória as ações dos grandes homens para o benefício das gerações ulteriores. ${ }^{32}$ A "biographia dos mais preclaros brazileiros" era tarefa a ser empreendida por meio do esforço coletivo de "dar vida” aos varões que, por diversas qualidades, pudessem ser “offerecidos ás nascentes gerações como typos de grandes virtudes". 33

A biografia inscrevia-se, em suma, no programa da historia magistra: como portadora de exempla, ela serviria, antes de tudo, para instruir a vida dos brasileiros no presente. Nessa perspectiva, a tarefa biográfica investia-se de um propósito eminentemente historiográfico, condição que, ao final, facultava a Cunha Barbosa estabelecer o paralelo entre o livro de Plutarco e a obra projetada para o IHGB:

\begin{abstract}
A nossa historia abunda de modelos de virtudes; mas um grande numero de feitos gloriosos morrem ou dormem na obscuridade, sem proveito das gerações subseqüentes. O Brazil, senhores, ... pode comtudo apresentar pela historia, ao estudo e emulação de seus filhos, uma longa serie de varões distinctos por seu saber e brilhantes qualidades. Só tem faltado quem os apresentasse em bem ordenada galeria, collocando-os segundo os tempos e logares, para que sejam melhor percebidos pelos que anhelam seguir os seus passos nos caminhos da honra e da gloria nacional. $^{34}$
\end{abstract}

Um mês após a fundação do Instituto, o primeiro secretário solicitava a remessa de documentos e materiais provenientes das diversas províncias. Encabeçando a lista de itens, aparecem as

noticias biographicas impressas, ou manuscriptas dos Brasileiros distinctos por suas lettras, virtudes, armas, serviços relevantes, ou por qualquer outra qualidade notavel, desde o descobrimento do Brasil.

Nestas, deveriam constar a "explicação de seus nomes, naturalidade, tempo em que viverão, e motivos de sua celebridade". ${ }^{35}$

\title{
Notícias biográficas dos brasileiros distintos
}

As biografias ocuparam uma seção específica na Revista, desde o seu segundo número, de julho de $1839 .{ }^{36}$ A partir dessa data, a sua publicação mantém-se fecunda e constante até 1849, somando um total de 72 notícias. Entre 1850 e 1860, há um visível declínio nas publicações, particularmente nos anos de 1853, 1854 e 1855, quando a rubrica Biographia dos brasileiros distintos desaparece, sem que deixem de ser publicados, contudo, artigos de conteúdo biográfico, como os elogios históricos e 
necrológios. A partir de 1856, a seção é retomada, não com a mesma regularidade e profusão da primeira década. De 1861 a 1882, o número de biografias incluídas é de 53. Nos anos posteriores, ou seja, entre 1883 e 1899, o decréscimo torna-se ainda mais acentuado, como pode ser verificado no quadro abaixo.

Quadro 1

Seção de Biographias de Brasileiros Distinctos

1839-1899

\begin{tabular}{|c|r|}
\hline Período & \multicolumn{2}{|c|}{$\begin{array}{c}\text { Biografias } \\
\text { publicadas }\end{array}$} \\
\hline $1839-1849$ & 72 \\
\hline $1850-1860^{37}$ & 16 \\
\hline $1861-1871$ & 27 \\
\hline $1872-1882$ & 26 \\
\hline $1883-1899$ & 13 \\
\hline & Total: \\
\hline
\end{tabular}

O número expressivo de textos incluídos na seção no período de 1839-1849 corrobora, em primeiro lugar, a idéia da incorporação da biografia ao projeto de elaboração da história nacional, formulado pela geração de fundadores do IHGB. Conforme assinalei anteriormente, a escrita das vidas de brasileiros distintos confundiase com a tarefa historiográfica em seu propósito fundamental de arrancar do esquecimento os nomes e os feitos dos que honraram e serviram à nação. Nesse momento, portanto, a aproximação entre os gêneros era mediada pela afirmação da função social, política e pedagógica da história. No entanto, como explicar o gradativo declínio nos usos da biografia após o primeiro decênio de existência do Instituto? Estaria o projeto histórico-biográfico vinculado primordialmente àquele primeiro grupo de sócios fundadores ao qual, não por acaso, pertencia o seu grande idealizador, o cônego Cunha Barbosa? O advento das gerações subseqüentes teria representado um certo esmorecimento do panteon de papel que se delineara desde os primeiros números da Revista?

Uma hipótese a ser considerada, sobretudo para o período posterior aos anos de 1880, é a de que o abandono do gênero biográfico pelos letrados do IHGB corresponderia a uma mudança significativa em seu projeto historiográfico. Mas, neste caso, como identificar os indícios e o alcance dessa mudança? O distanciamento em relação à biografia seria a prova mais tangível de que a escrita da história perdia, 
paulatinamente, a finalidade magisterial de fornecer lições e exemplos a serem imitados no presente, através do relato dos acontecimentos pretéritos da nação?

Tais questões me obrigam a retomar a análise acerca das condições que, em um primeiro momento, tornaram possível a aproximação entre os gêneros. Antes, porém, de identificar os modos pelos quais a biografia integrou-se às tarefas do historiador, é necessário entender como ela se tornou um instrumento institucional importante na elaboração e delimitação de critérios de distinção entre os próprios letrados. ${ }^{38}$

\section{O elogio dos mortos e a consagração dos vivos}

Nos dez anos iniciais de existência da Revista (1839-1849), a impressão de notícias biográficas seguia o regimento adotado para os demais textos do periódico. De modo geral, eram trabalhos lidos em sessões plenárias ou remetidos pelos sócios, e sempre encaminhados à apreciação dos integrantes da Comissão de História. Assim, na sessão realizada em 20 de abril de 1839, o sócio Balthazar da Silva Lisboa ofereceria ao Instituto um manuscrito sobre a vida de alguns brasileiros ilustres. ${ }^{39} \mathrm{Na}$ reunião seguinte, registra-se o parecer favorável à sua publicação, justificada pelas valiosas informações que tornariam conhecidos "muitos nomes distinctos, quase absorvidos pelo esquecimento, e ... outros muitos que já vivem nas paginas da nossa Historia”. ${ }^{40}$ Os apontamentos biográficos compostos por Silva Lisboa não chegariam a ser publicadas na seção. ${ }^{41}$ Falecido em agosto de 1840, o sócio honorário do Instituto teria, entretanto, o relato de sua vida incluído na galeria de brasileiros distintos. ${ }^{42}$

Embora a transcrição de pareceres acerca de biografias nos relatórios das sessões posteriores tenha sido relativamente rara, supõe-se que grande parte desses textos continuou a ser submetida à avaliação. Tal foi o caminho seguido pelas biografias dos poetas Santa Rita Durão e Antônio José da Silva e dos padres José de Anchieta e Manoel da Nóbrega. Após o exame de cada um destes trabalhos, a comissão encarregada recomendava a sua publicação nos seguintes termos:

Biographia de Santa Rita Durão, pelo Sr. Francisco Adolpho de Varnhagen. Producção interessante e curiosa, como tudo o que tem até aqui sahido da penna d'este illustre escriptor. Esta noticia recommenda-se por noticias de factos não conhecidos, e de pormenores que dão um novo interesse á vida do celebre poeta.

Biographia de Antonio José, pelo mesmo auctor. Contém algumas indagações de importância sobre o processo e sobre os tormentos do infeliz poeta cômico.

Biographia de José de Anchieta, e de Manoel da Nóbrega, por Ignácio Accioli de Cerqueira e Silva. Parecem trabalhos feitos sobre as obras dos jesuítas com bastante critério. ${ }^{43}$ 
Diferentemente dos textos de Balthazar da Silva Lisboa, os trabalhos de Varnhagen e de Cerqueira e Silva, depois de aprovados por meio desse juízo apreciativo, foram incluídos na seção. Como as demais produções historiográficas, as biografias propiciavam certa visibilidade aos membros da instituição, pois, de modo geral, traziam a assinatura de seus autores. Dentro de seus propósitos de construir um saber específico sobre a nação brasileira, é preciso lembrar, contudo, que o IHGB organizou-se, nos primeiros anos, segundo princípios não estritamente regidos pelo mérito intelectual acadêmico, mas bem mais próximos de uma sociedade de corte, fundada na hierarquia de funções e papéis sociais. ${ }^{44} \mathrm{O}$ programa de edificação coletiva da história nacional nascia, assim, sob os auspícios do mecenato real. O Estado imperial funcionava como ponto de irradiação e de convergência da produção historiográfica que começava a ser forjada nos círculos restritos da elite letrada acadêmica.

Elaborar notícias sobre as vidas de brasileiros distintos implicava buscar no passado e arrancar do esquecimento os nomes daqueles que prestaram serviços ao Império do Brasil. Entre estes, por que não incluir aqueles que, no presente, lançavamse à monumental tarefa da investigação e da escrita da história nacional? Por sua condição de servidores do Estado, não seriam alguns desses letrados igualmente dignos de um trabalho de memória e de louvor por sua ilustração e empenho na civilização do país?

Não foram poucos os consócios, e o primeiro deles seria o já citado Balthazar da Silva Lisboa, a figurar na galeria dos brasileiros ilustres. ${ }^{45}$ De qualquer modo, as histórias das vidas dos sócios do IHGB conquistariam um espaço próprio e permanente no periódico. Necrológios e elogios históricos, gêneros que, por excelência, eram praticados nas instituições acadêmicas ilustradas, passaram a ser recitados nas reuniões quinzenais do Instituto e posteriormente publicados em separado ou incluídos em atas das sessões. $^{46}$

Importante assinalar que entre as principais incumbências do orador, prevista nos estatutos da agremiação, estava precisamente a de fazer o elogio, bem como o discurso fúnebre na cerimônia de sepultamento dos sócios falecidos. ${ }^{47}$ A tarefa de evocação das qualidades morais dos mortos, longe de se resumir a um simples exercício de oratória, assumiria uma importância estratégica dentro da instituição. Não por acaso, esses discursos seriam objeto da seguinte proposta do primeiro secretário, Cunha Barbosa, aprovada em sessão plenária de maio de 1841: 
Como seja mui difficil haverem-se esclarecimentos sobre as vidas dos nossos socios quando o orador tem de formar a sua biographia na fórma do costume; proponho que pela nossa Revista, ou por qualquer outro meio, se avise aos socios para que possam mandar em memoria lacrada, e com declaração no sobrescripto, ao archivo do Instituto, os esclarecimentos sobre a propria vida de cada um, as quaes memorias só se abrirão quando constar a morte do socio a que pertencem ${ }^{48}$

Não se tratava apenas de louvar os mortos, mas de garantir a fidedignidade da sua memória: esta deveria ser a preocupação tanto daqueles que optassem por depositar previamente nos arquivos o relato autorizado de suas próprias vidas, quanto dos que se incumbissem da laudatio funebre dos consócios falecidos. Indissociáveis dos cerimoniais de entronização acadêmica, os elogios e necrológios, mais do que discursos puramente ornamentais, tornaram-se também instrumentos de autoconsagração dos vivos e unificação de valores e aspirações coletivas. ${ }^{49}$

\section{Pelas letras, armas e virtudes}

O Instituto, lembrando-se do pensamento de um philosopho quando dizia que a historia do mundo sem a historia dos sabios é como a estatua de Poliphemo, a quem se arrancasse o olho, perdendo assim o que dava a seu semblante expressão e vida, desvela-se em dar a luz a biographia dos Brasileiros distinctos por letras, armas, virtudes, \&c, cujos nomes merecem chegar ao respeito dos vindouros. Elle acrescenta a esta util publicação a biographia dos homens illustres, que no Brasil tem prestado importantes serviços, posto que não nascidos n'esta parte do mundo. Tempo virá em que tambem salvemos do esquecimento os nomes d'outros, que tem introduzido na nossa patria cousas interessantes á industria, agricultura, commercio e artes. Januário da Cunha Barbosa. ${ }^{50}$

O primeiro aspecto que chama a atenção na análise da seção de biografias da Revista é o título em aberto (etc.), marcado por variações que, de imediato, sugerem impasses e hesitações dos seus colaboradores quanto à demarcação da nacionalidade dos eleitos para a posteridade. ${ }^{51}$ De fato, a seção que surge em julho de 1839 , intitulada Biographia dos brasileiros distinctos por lettras, armas e virtudes, mantém a fórmula até 1850, quando se transforma em Biographias de brasileiros distinctos ou de indivíduos illustres que serviram no Brasil ... Ainda em 1843, a biografia do português José Fernandes Vieira, transcrita da revista O Panorama e de autoria de Varnhagen, era precedida da seguinte nota de pé de página:

O Instituto publicará também as biographias de varões illustres, que posto não sejam brasileiros por nascimento, todavia o são por acções gloriosas, e por haverem passado grande parte de sua vida n’este paiz. Os serviços por elles prestados aqui recommendam sua memoria á veneração dos brasileiros. ${ }^{52}$ 
A advertência não poderia ser mais eloqüente, ao introduzir como critério preponderante para a eleição dos ilustres ações e serviços prestados ao Brasil, independentemente da condição de terem aqui nascido. ${ }^{53}$ Tal idéia fazia sentido, sobretudo porque favorecia a constituição de uma galeria nacional com raízes no período anterior a 1822, estabelecendo a linhagem de varões ilustres desde os tempos coloniais. No entanto, o problema dos requisitos para a inclusão no panteon dos distintos permaneceria longe de uma solução consensual por parte dos colaboradores da Revista. É importante considerar que o impasse que se manifestava em nível acadêmico acompanhava o processo político de construção da nação nos quadros do Império e, sobretudo, o equacionamento das diferentes “peças do mosaico” identitário em disputa na composição da nacionalidade brasileira no decurso do Oitocentos. ${ }^{54}$

Talvez se possa atribuir a essa dificuldade as alterações sutis que, entre 1850 e 1852, fizeram o título da seção oscilar na referência aos indivíduos illustres que bem servissem o Brasil e ilustres que serviram ao Brasil e no Brasil. De um modo geral, verifica-se que a fórmula Biographia de Brasileiros distinctos por lettras, armas e virtudes predomina, embora a variação Brasileiros illustres também tenha sido recorrente, sobretudo a partir de 1856.

De acordo com o Dicionário Moraes e Silva, em edição de 1823, o adjetivo distincto, quando especificamente usado na expressão homem distincto, qualificava aquele "que não era comum, nem do povo”. ${ }^{55} \mathrm{O}$ fator de distinção delimitado pelo título da seção estava nas letras, armas e virtudes. A tópica das armas e letras, dominante na retórica dos letrados quinhentistas lusitanos, pressupunha a articulação na esfera individual entre duas funções: a ação e a palavra. ${ }^{56}$ Em meados do século XVI, a fórmula foi copiosamente glosada e integrada ao que Luís de Sousa Rebelo chama de um ideal de humanismo cívico sui generis. O letrado português do Quinhentos encontrava-se, então, em completa sintonia com a política da Coroa e pronto a aceitar o empenho que a adesão a tal política dele iria exigir. O cronista João de Barros salientava, em seu Panegírico de D. João III (1533) que já não era possível manter-se o conflito entre as armas e as letras, em virtude do interesse que por ambas tinha o monarca, “em cuja Corte floresciam com invulgar esplendor”. 57

Em Camões, identifica-se o uso emblemático da tópica, explorada sob incontáveis matizes. Nos Lusíadas, por mais de uma vez, são celebrados os méritos da distinção dual, cujo modelo os varões lusitanos deveriam buscar nos grandes heróis 
gregos e romanos, dotados de engenho, amor às artes e à eloqüência tanto quanto de bravura e aptidão com a espada - afeitos, em suma, às armas e às letras. Nas estrofes finais do Canto $V$, Camões compara os grandes generais da antiguidade com os militares portugueses; os primeiros, em meio às piores batalhas, dedicavam-se à poesia enquanto os lusitanos, não dotados desses mesmos dons, apenas se preocupavam com embates e façanhas:

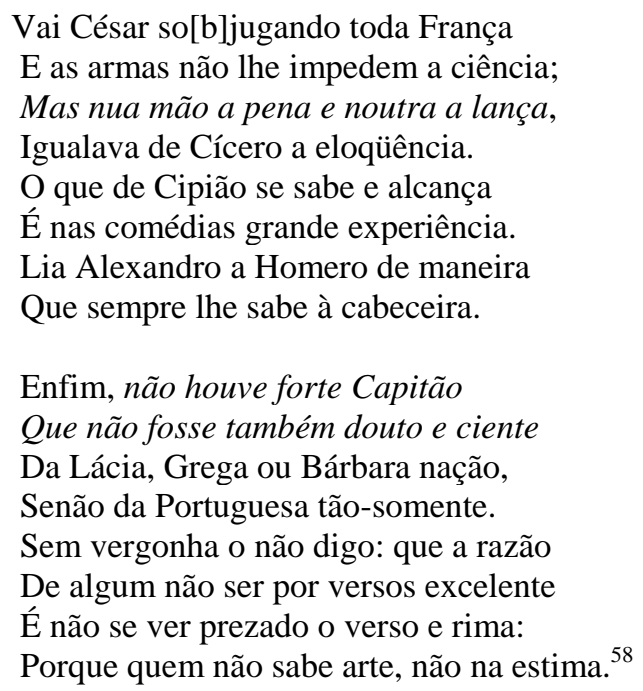

Os grandes feitos militares e o domínio das armas unicamente não são suficientes na arquitetura do modelo de herói português segundo a perspectiva camoniana. De fato, a falta de estima pelas letras implica não apenas a rudeza dos heróis, mas, sobretudo, a limitação das suas virtudes, na medida em que estas deixam de ser cantadas, louvadas e, portanto, imortalizadas. Pois é somente no canto do poeta que “o feito histórico atinge verdadeiramente a sua plenitude heróica e sublime”, ou seja,

ao passado grandioso da pátria é necessário que se ajunte a inteligência dele, pela arte, a fim de que o acidental e particular dos feitos alcance o estatuto universal da virtude e excelência, que comunica perfectibilidade aos seres. ${ }^{59}$

Mais do que o elogio de um feito histórico, a epopéia em Camões é concebida "como estímulo, louvor e documento das proezas memoráveis dos antepassados, de virtudes sublimes dos heróis e de esperanças futuras do Reino”. 60

Assim como os poetas, os historiadores também são artífices da memória e, tal como a poesia épica, a história é escrita para a posteridade com uma promessa de imortalidade. ${ }^{61} \mathrm{E}$, neste caso, a proximidade torna-se ainda mais significativa quando se 
relaciona à fórmula da historia magistra uma ordem do tempo em que as ações no presente são orientadas pelos exemplos do passado a serem imitados. Nos quadros do expansionismo imperial lusitano, a tópica das armas e letras foi argumento crucial utilizado na narrativa histórica da conquista pelos portugueses dos territórios "bárbaros", desprovidos dos valores da civilização. ${ }^{62}$ Os grandes valores que dão ao homem a verdadeira medida da sua dimensão - a virtude militar e moral; a fama e a glória - logram-se tanto na luta pela pátria, no combate pela ampliação da cristandade e do império, quanto no cultivo e na estima das humanidades. ${ }^{63}$

O uso da fórmula das armas e letras no título da seção de biografias da Revista do IHGB merece ser analisado sob dois aspectos. O primeiro e mais evidente deles é que o topos reforça a dimensão de natureza política que, ineludivelmente, articulava-se ao empreendimento historiográfico do Instituto e à legitimação de um projeto civilizador inaugurado pela colonização portuguesa. ${ }^{64}$ Não por acaso, são versos de Camões que servem de epígrafe à biografia, assinada por Varnhagen, do primeiro donatário da capitania da São Vicente, Martim Afonso de Sousa: “Tanto em armas illustre, em toda a parte/Quanto em conselho sábio, e bem cuidado”. ${ }^{65}$

Em segundo lugar, a fórmula, em toda a sua conotação metafórica, sinaliza critérios fundamentais de distinção dos indivíduos e seus feitos nos quadros mais amplos da história da nação. Desse modo, no panteon erigido nas páginas da Revista, identificam-se duas categorias de brasileiros distintos: os funcionários de carreira do Estado e os religiosos. O perfil dos biografados corresponde ao da elite política e letrada imperial e, por conseguinte, apresenta-se como uma espécie de galeria de espelhos que reflete e se confunde com o próprio quadro de fundadores e membros do IHGB - todos servidores e dignitários do Império. ${ }^{66}$ Assim, nomes como os da família de Francisco de Lemos de Faria Pereira Coutinho (1735-1822), nascido no Brasil e nomeado reitor na Universidade de Coimbra em 1770, despontam como representativos dos motivos da celebridade que, segundo a prescrição de Cunha Barbosa, deveriam constar nas notícias biográficas dos brasileiros distintos. Em texto assinado por ele próprio, a tópica que dá título à seção é usada para definir a trajetória de vida do seu biografado, Clemente Pereira de Azeredo Coutinho (1731-1774), irmão de Francisco de Lemos e governador da capitania do Maranhão:

De quatro irmãos que eram, descendentes de um honrado Brasileiro, que entre seus avós contava muitos illustres servidores de Estado, foi Pereira de Azeredo o que desviando-se da carreira 
commumente seguida n'esses tempos dos mancebos illustres, procurou a gloria das armas apoiada na gloria das lettras. ${ }^{67}$

No rol dos religiosos, figuras como Manoel da Nóbrega (1517-1570), Antonio Vieira (1608-1687) e José de Anchieta (1534-1597), os dois primeiros nascidos em Portugal e o último natural das Ilhas Canárias, compõem parcela significativa do corpus biográfico entre 1839 e 1849: do total de 72 biografados no período, 19 são integrantes de ordens religiosas, e igualmente considerados servidores da nação. Em razão da sua presença expressiva na lista de biografados, talvez seja possível atribuir-lhes, como o fez Armelle Enders, a condição de pilares da galeria nacional e verdadeiros avatares do heroísmo cívico. ${ }^{68}$

\section{Traçando a biografia com escrupulosa exatidão}

Da mesma forma que a construção da memória dos sócios falecidos, a compilação de biografias de brasileiros, a partir de anais, nobiliarquias ou quaisquer outras fontes, não se fazia sem a observação de certos critérios relacionados à ambição de veracidade com que a tarefa era concebida. E, nesse caso específico, a pretensão de produzir relatos biográficos fidedignos mostrava-se em plena consonância com a missão programática de “reparar os erros e preencher as lacunas da nossa história”, incorporada pelos letrados do IHGB. Passados quatro anos da sua fundação, a idéia é reiterada pelo presidente, Visconde de São Leopoldo:

\footnotetext{
Nosso Instituto, esmerilhando documentos, por incuria ou malicia escondidos, para coordenar a historia do Brasil, depois de afinados, como os metaes preciosos, no crisol da critica severa, e de receberem o cunho da autenticidade; traçando a biographia dos compatriotas famigerados com a escrupulosa exactidão do operario inteligente, para não confundir com o diamante o cristal rocha, e de modo lapidal-o que brilhe, afim de n'esses exemplares espelharem-se os vindouros; ... ${ }^{69}$
}

Ainda em 1841, a preocupação com a “escrupulosa exactidão” servira de justificativa para o parecer de Thomaz José Pinto Serqueira, integrante da comissão de História, acerca das biografias de brasileiros, impressas na Corografia do Algarve da Academia Real de Ciências de Lisboa. ${ }^{70}$ Encarregado de examinar a obra, Serqueira apresentaria um juízo desabonador à publicação dos artigos dedicados à vida dos marechais Antonio José da Franca e Horta, Gonçalo Antonio da Fonseca e Sá, e do 
Visconde da Laguna, Carlos Frederico Lecor, pois continham erros que deveriam ser corrigidos por se tratarem de fatos da história do Brasil. ${ }^{71}$

O mesmo critério de "purificação dos erros” da história nacional está presente nos comentários e observações acrescidos à biografia de Bernardo Vieira Ravasco, extraída da Bibliotheca Lusitana. ${ }^{72}$ Neste caso, o equívoco fundamental dizia respeito à própria data de descobrimento do Brasil. A notícia biográfica incluía a citação de um fragmento da principal obra de Ravasco, Descripção topographica, ecclesiastica, civil e natural do Estado do Brasil, onde era feita menção à “descoberta desta parte da América em 3 de Maio de 1500”, ao que se adicionaria a seguinte nota explicativa:

\begin{abstract}
Admira que o sabio escriptor Diogo Barboza Machado deixasse passar sem reparo um tão grande erro na sua Bibliotheca Lusitana, sacrificando talvez a verdade da historia á fidelidade de transcrever tal e qual o que se encontra no Ms. [manuscrito] de Bernardo Vieira Ravasco, do qual diz que possuia uma copia. E quem sabe se houve n'isso lapso de penna ou de um ou de outro escriptor? O certo é que o Brasil não foi descoberto no dia 3 de maio, e sim, como diz o sabio Bispo Jeronimo Ozorio, em sua obra ... e se assim foi, como se não pode duvidar, de certo enganou-se Ravasco. Cabral partiu das regiões Brasilicas para o Cabo da Boa Esperança no dia 5 de Maio; e no dia 3 d'este mez nenhuma celebridade tem na historia do descobrimento do Brasil. (Nota do Redactor da Revista). ${ }^{73}$
\end{abstract}

A despeito do equívoco impresso na obra, outras sete notícias da seção aparecem como transcrições da Bibliotheca Lusitana, evocada no discurso inaugural do Instituto, quando Cunha Barbosa afirmara que, nela, encontravam-se “os nomes de alguns brasileiros preclaros”. ${ }^{74}$ A coleção de biografias, organizada e redigida pelo abade português Diogo Barbosa Machado (1682-1772), apresenta-se como referência importante para a compreensão do projeto biográfico dos sócios do Instituto. Os quatro volumes in folio impressos em Lisboa, entre 1741 e 1759, constituem o primeiro grande catálogo de autores da língua portuguesa, elaborado ao longo de 40 anos de trabalho. ${ }^{75}$ A invenção de um patrimônio literário lusitano por Barbosa Machado assenta-se na crítica documental, concebida como avaliação metódica da veracidade e autenticidade dos testemunhos escritos e ordenação cronológica dos mesmos, procedimentos que vinham sendo preconizados e praticados no âmbito da Academia Real de História, da qual o bibliógrafo era membro fundador. ${ }^{76}$ Algumas indicações metodológicas importantes acerca da sua elaboração encontram-se em seu Prólogo e, por isso, merecem ser citadas em toda a sua extensão:

Saõ as Bibliothecas ou dispostas por ordem Alphabetica, como observaraõ huns, ou Chronologica, como seguiraõ outros, aquelles eruditos Amphitheatros em cuja espaçosa circumferencia apparecem animados os Oráculos de todas as sciencias, que para nunca 
emmudecerem deixáraõ impressa nos fecundos partos dos seus engenhos a mais nobre de todas as potencias. Nellas se fazem patentes as Pátrias, que illustràraõ com os seus nascimentos, como os lugares que foraõ Religiosos depósitos de suas cinzas. Relataõ-se as acçoens memoráveis das suas vidas para documentos exemplares da vida moral, e política. Com a luz sempre clara da Chronologia se desterraõ as sombras dos Anacronismos, que confundem a verdadeira Epocha dos Annos. Restituese ao seu verdadeiro Author a obra injustamente uzurpada pela afectada sciencia dos Plagiários. Defende-se com fundamentos sólidos o berço em que se animàraõ alguns de seus illustres filhos contra a opinião mal fundada de outras Naçoens ambiciosas de taõ grande gloria. $^{77}$

Na obra de Barbosa Machado, os preceitos da crítica documental combinam-se ao estilo essencialmente laudatório e encomiástico das notícias biográficas dos escritores portugueses, através das quais se atesta a glorificação tanto das suas vidas como das suas obras. Os grandes feitos em vida ou, por vezes, o caráter predestinado da morte de um autor, funcionam como testemunhos do valor da sua obra literária. ${ }^{78}$ Aqui, impõe-se uma breve observação sobre as similitudes entre a biografia e o panegírico, na medida em que esses gêneros passam a ser concebidos como repertório de exemplos, constituídos por discursos de louvores das qualidades morais dos grandes homens. Como bem assinala Alcir Pécora, o panegírico, “embora descreva ações passadas, não o faz referindo o que ouviu dizer e reteve na memória, mas produzindo uma narrativa à qual dá fé,. ${ }^{79} \mathrm{E}$, precisamente por se tratar de um discurso que autoriza a verdade dos feitos e das ações, pôde se incorporar a outras formas historiográficas como o tratado, a relação, a corografia, a crônica. ${ }^{80}$ A Bibliotheca de Barbosa Machado deve ser considerada, em suma, a materialização de um esforço duplo de ordenação do passado e de construção da memória das vidas exemplares dos ilustres representantes das letras lusitanas. ${ }^{81}$

Nessa perspectiva, adquire sentido o empenho dos sócios do IHGB em um projeto historiográfico que se compatibilizava com a pesquisa e a composição biográficas. Escrever vidas e narrar a história remetiam a modalidades discursivas distintas, porém passíveis de ser submetidas a um mesmo regime de fidedignidade e verdade. Parece indiscutível, portanto, que a opção biográfica dos nossos letrados adequou-se às injunções da disciplina histórica tal como esta foi sendo concebida e praticada no Brasil do século XIX. Mas, como identificar, nesse momento, a incorporação das tarefas do biógrafo ao trabalho do historiador?

O exemplo de Francisco Adolfo de Varnhagen - autor do maior número de biografias publicadas na seção - talvez forneça algumas indicações. A premência da coleta de documentos e fontes para a elaboração da história do Brasil o levaria a empreender um périplo incansável pelos arquivos da Europa. Em julho de 1841, durante 
estada em Portugal, ele escreve ao primeiro secretário Cunha Barbosa escusando-se por não remeter nenhum trabalho para impressão na Revista naquele momento. Entretanto, anunciava que em suas pesquisas nos arquivos portugueses incluiria também a averiguação de biografias de alguns nomes ilustres:

\begin{abstract}
Por ora, só me occupo de colligir, e todo o tempo acho para isso pouco, ainda que bem deligencio aproveital-o. Tenho tambem precizão de ir a Coimbra e a Évora; mas não sei se mais será isso possivel. Naquella cidade desejava eu ver dos livros da Universidade se se encontram esclarecimentos àcerca das biographias de certos brasileiros illustres, taes como Fr. Gaspar, Claudio Manoel da Costa, Manuel Ignacio da Silva Alvarenga, Arruda da Camara, Mello Franco, Dr. Hyppolito, Dr. Couto, Ferreira Cardozo e Luiz Joaquim Henriques de Paiva, conforme tratei com V. Sa, e prometti ao nosso Instituto. ${ }^{82}$
\end{abstract}

Naquele ano, duas biografias de sua autoria haviam sido incluídas na seção, a primeira delas, de Francisco de Lemos Faria Pereira Coutinho, e a outra, de Salvador Correa de Sá Benevides, ambas escritas no Brasil. Dois anos mais tarde, uma série de sete artigos biográficos, sob a rubrica de Biographia de brasileiros distinctos, traria a sua assinatura. Entre estes, chama a atenção o complemento feito pelo autor à biografia de Sá Benevides, cuja primeira versão fora publicada em 1841. Sob a forma de uma carta dirigida ao redator da Revista, Varnhagen apresenta retificações àquele texto, com base em documentos inéditos que ele anuncia ter encontrado em arquivos portugueses. O procedimento seria adotado em outras de suas notícias biográficas, como a de Tomás Antônio Gonzaga, cuja primeira versão de 1849 recebe um aditamento no ano seguinte, ou ainda a de Ignácio de Alvarenga Peixoto, publicada em 1850 e reescrita em 1867 com o subtítulo de retoques á sua biografia ...

Embora não possa ser considerado um traço marcante nos trabalhos dos demais colaboradores da seção, o uso da prova documental pelo Visconde de Porto Seguro, bem como a postura metódica de Cunha Barbosa, indica, de imediato, que a escrita de biografias pressupunha o uso de procedimentos com que então se buscava disciplinar a construção do conhecimento histórico. Do mesmo modo, as notícias biográficas contidas em genealogias, anais e obras similares eram coletadas, coligidas e avaliadas em sua autenticidade, como documentos a serem utilizados na elaboração da história geral do Brasil, sem que se colocasse o problema da sua incorporação como instrumento de pesquisa.

Em que medida a composição de relatos biográficos fidedignos e documentados já não estaria, no século XIX, tacitamente integrada às tarefas do historiador, sem que isso implicasse uma auto-atribuição específica da função de biógrafo? Admitida essa hipótese, não seria igualmente procedente investigar as possíveis relações entre a 
pesquisa histórica, a escrita biográfica e as práticas eruditas de coleta e compilação de documentos ${ }^{83}$ Uma carta de Varnhagen transcrita em ata da sessão de 19 de janeiro de 1843 sugere alguns elementos para o exame da questão. Em Lisboa, o sócio efetivo do IHGB exulta a situação favorável em que se encontrava, "graças á munificencia do nosso Augusto Imperador”, para reunir “os elementos para a organização de uma conveniente Historia da civilização do Brasil”, e conclui:

\begin{abstract}
Porém, ainda que as minhas averiguações hoje sejam relativas ás epocas mais remotas, não me descuido de diligenciar e obter copias do que é importante ainda mais moderno. ... Com este mesmo fim faço ainda diligencias para obter a celebre Nobiliarchia Paulistana, de Pedro Taques, tão citada e gabada por Frei Gaspar ... Se eu conseguir uma occasião de voltar á Coimbra, farei n'isto consistir um dos meus empenhos; que os outros já encetados são os apontamentos biographicos de nossos fallecidos patricios que alli pagassem o tributo ás lettras, e bem assim o fazer tirar copias de dois distinctos fluminenses D. Francisco de Lemos e seu irmão João Pereira Ramos. $^{84}$
\end{abstract}

O extenso relato das diligências investigativas de Varnhagen não somente revela que as tarefas de repertoriar documentos e obter cópias fidedignas definia o ofício do historiador no século XIX, mas serve igualmente para que se examine o suposto estatuto auxiliar atribuído à biografia, submetida aos desígnios mais amplos da escrita histórica. Armelle Enders entende que, para a maioria dos historiadores brasileiros do Oitocentos, a composição de apontamentos biográficos servia "para colorir afrescos mais vastos, para ornar a História Geral com alguns retratos”. ${ }^{85}$ Todavia, o caso Varnhagen sugere que essa relação não era simplesmente ornamental. Se as biografias tinham por propósito fornecer elementos subsidiários à elaboração de uma narrativa histórica geral, por que o historiador se dedicou com tanto afinco ao trabalho de redigir, e até mesmo retificar, tantos textos do gênero, enviando-os para publicação em seção específica da Revista? Se admitirmos a função pictórica que a biografia supostamente teria para os historiadores do século XIX, como identificar os seus usos e a sua posterior incorporação às obras propriamente históricas? Na ponderação dessas questões, é importante considerar como o próprio Varnhagen, dirigindo-se em carta ao Imperador, justificaria os seus estudos tanto no campo da história como no da literatura e da biografia dos ilustres brasileiros:

E aqui repetirei de novo a V.M.I. o que já Lhe disse em 1851, que o motivo principal porque eu emprehendera o florilégio e escrevia biographias de Brazileiros de todas as províncias era para ir assim enfeixando-as todas e fazendo bater os corações dos de umas províncias em favor dos das outras, infiltrando a todos nobres sentimentos de patriotismo de nação, único sentimento que é capaz de desterrar o provincialismo excessivo, do mesmo modo que desterra o egoísmo, levando-nos a morrer pela pátria ou pelo soberano que personifica seus interesses, sua honra e sua gloria. ${ }^{86}$ 
O registro da vida de brasileiros ilustres era, em suma, parte do empreendimento a que o historiador se referia como objeto central das suas preocupações e da sua História Geral: a promoção da unidade e da integridade do Brasil como um Império futuro. ${ }^{87}$ No entanto, mesmo submetida às regras da crítica documental, a biografia não exigiria a adoção de códigos próprios de escrita e, portanto, diferenciados do texto historiográfico? Não se pressupõe que, nas biografias, seja feito o elogio aos grandes feitos e às qualidades morais dos valorosos “servidores da nação”, de modo que eles sejam não somente lembrados, mas imitados pelas gerações seguintes? Neste sentido, caberia ao historiador responder: quais as vidas merecem ser objetos de um relato biográfico, quais indivíduos podem ser enquadrados na categoria de distintos ou ilustres? Por fim, tanto quanto dar fé, como dar prova da distinção dos biografados?

Os questionamentos que surgem com as biografias de Varnhagen podem ser endereçados a todos os letrados que, no desempenho do ofício de historiador, conciliavam as tarefas de escrever a grande narrativa da nação e, ao mesmo tempo, erigir a galeria ordenada de seus ilustres protagonistas. Fundadas na coleta e na crítica documental, uma e outra tarefa remetia, no entanto, a problemas distintos, traduzindo-se em diferentes desafios.

OLIVEIRA,Maria da Glória de. Plotting lives of distinct Brazilians with scrupulous accuracy: biography, scholarship and writing of history in the Historical and Geographical Brazilian Institute Review (1839-1850). História, São Paulo, v. 26, n. 1, p 154-178, 2007.

Abstract: The article aims at reflecting on the biographic texts publications in the Historical and Geographical Brazilian Institute Review between 1839 and 1850. The hypothesis to be examined is that the biographies of illustrated Brazilians were a genre of writing linked to its place of production and submitted to procedures and rules of a historiographical operation.

Keywords: writing of history, biography, Historical and Geographical Brazilian Institute

Artigo recebido em 04/2007. Aprovado em 06/2007.

\section{NOTAS}


* Doutoranda do Programa de Pós-Graduação em História Social/UFRJ, CEP 20051-070, Rio de Janeiro/RJ. Bolsista CAPES. E-mail: mgloriaprof@gmail.com.

${ }^{1}$ BARBOSA, Januário da Cunha. Discurso do Primeiro Secretário Perpétuo do Instituto. Revista do IHGB, t.I, p.14. 1839. Para as citações de textos da Revista, manterei sempre a grafia original e utilizarei a sigla RIHGB.

${ }^{2}$ Biographia dos Brasileiros Distinctos por Lettras, Armas, Virtudes etc. José Basílio da Gama. RIHGB, t.I, n.2, $1^{\text {a }}$. Ed., pp. 139-141.

${ }^{3}$ Também é possível encontrar um mapeamento específico da seção em SANCHEZ, Edney C. T. Revista do Instituto Histórico e Geográfico Brasileiro: um periódico na cidade letrada brasileira do século XIX. São Paulo/Campinas: IEL/Unicamp, 2003. p.108-112. (Dissertação de Mestrado)

${ }^{4}$ GUIMARÃES, Lúcia M. P. Debaixo da imediata proteção de Sua Majestade Imperial: o Instituto Histórico e Geográfico Brasileiro (1838-1889). RIHGB, Rio de Janeiro, a. 156, n. 388, jul./set. 1995, p.510-512. A análise quantitativa pioneira sobre o material da Revista está em POPPINO, Rollie. A century of the Revista do Instituto Histórico e Geográfico Brasileiro. The Hispanic American Review, Durham, 33 (2), 1953.

${ }^{5}$ GUIMARÃES, Lúcia M. P. op. cit., p.522.

${ }^{6}$ Para a historiografia dos acadêmicos brasílicos no século XVIII, Iris Kantor também chama a atenção para a diversidade de estilos narrativos adotados e interpreta essa "indeterminação da prosa historiográfica" como uma "estratégia discursiva da afirmação da identidade americana". KANTOR, I. Esquecidos e Renascidos. Historiografia Acadêmica Luso-Americana (1754-1759). São Paulo: Hucitec; Salvador: Centro de Estudos Baianos/UFBA, 2004. p.243-244.

${ }^{7}$ A questão serviu de tema para o concurso, instituído em 1840, no qual o Instituto oferecia um prêmio ao trabalho que apresentasse o melhor plano para a escrita da "história antiga e moderna do Brasil". A dissertação Como se deve escrever a história do Brasil, do naturalista bávaro Carl Fiedrich von Martius (1794-1868), foi a escolhida, diante de um único concorrente, o sócio Henrique Wallenstein, com a Memória sobre o melhor plano de se escrever a História Antiga e Moderna do Brasil. Para uma análise do plano de Martius, ver CEZAR, Temístocles. Como deveria ser escrita a história do Brasil. Ensaio de história intelectual. In: PESAVENTO, S. J. (org.) História Cultural: experiências de pesquisa. Porto Alegre: Editora da UFRGS, 2003. p.173-208.

${ }^{8}$ REVEL, J. Ressources narratives et connaissance historique. Enquête, n.1, p.51 e 68, 1995.

${ }^{9}$ Nesse sentido, o programa historiográfico dos acadêmicos brasílicos seiscentistas já se orientava essencialmente para a elaboração de memórias históricas - "aparato crítico de fontes documentais e bibliográficas, tábua cronológica, carta geográfica, corografia, genealogia, catálogo de autoridades, etc.” - como instrumento prévio para a escrita de uma "história universal da América Portuguesa". KANTOR. Op. cit., p.77.

${ }^{10}$ RIHGB, t.XV, p.485, 1852.

${ }^{11}$ CEZAR, Temístocles. Livros de Plutarco: biografia e escrita da história no Brasil do século XIX. Métis: História \& Cultura. Revista de História da Universidade de Caxias do Sul, v.2, n.3, p.74, jan.jun./2003.

12 “A tendência histórica básica dos mais diferentes gêneros é a de desenvolver formas 'mistas', com dinamicidade relativa nos distintos períodos, que impedem definitivamente a descrição de qualquer objeto como simples coleção de aplicações genéricas” (PÉCORA, Alcir. Máquina dos gêneros. São Paulo: Edusp, 2001. p.12).

${ }^{13}$ MOMIGLIANO, Arnaldo. Les origines de la biographie em Grèce ancienne. Paris: Circé, 1971. p.25.

${ }^{14}$ A expressão "panteon de papel” é usada por Jean-Claude Bonnet em seu estudo sobre o culto dos grandes homens na França. BONNET, J. C. Naissance du Panthéon. Essai sur le culte des grands hommes. Paris: Librairie Arthème Fayard, 1998.

${ }^{15}$ ARARIPE, Tristão de Alencar. Indicações sobre a história nacional. RIHGB, t.LVII (2a parte), p.263, 1894.

${ }^{16}$ Apesar de ter aparecido na Revista em 1894, o próprio autor credita a origem do texto à conferência por ele realizada em 7 de fevereiro de 1876, perante a Associação Promotora da Instrução, no Rio de Janeiro.

${ }^{17}$ Idem, p.260.

${ }^{18}$ Idem, p.273.

${ }^{19}$ Idem, p.274. Em nota nesta mesma página, o autor informa ter traduzido para o português a obra de Plutarco. Sobre essa tradução, Araripe escrevera um artigo em 1848, no jornal “O Cearense” divulgando a publicação do livro que, ao que parece, não se concretizou (ARARIPE, Tristão de Alencar. A vida dos homens ilustres. O Cearense. Fortaleza, 24 de abril de 1848. Publicação Literária, p.4). 
${ }^{20}$ KOSELLECK, Reinhart. Historia magistra vitae. In: Futuro pasado. Para una semántica de los tiempos históricos. Barcelona: Ediciones Paidos, 1993. p.43.

${ }^{21}$ Idem, p.44. Para uma análise da definição ciceroniana de história, ver também HARTOG, François (org.). A história de Homero a Santo Agostinho. Belo Horizonte: Editora UFMG, 2001. p.181-182.

${ }^{22}$ HARTOG, F. Orateurs et historiens. In: Évidence de l'histoire. Ce que voient les historiens. Paris: Éditions de l’École dês Hautes Études em Sciences Sociales, 2005. p.43.

${ }^{23}$ A noção de regimes de historicidade, tal como a define François Hartog, denota os diferentes modos de articulação das categorias de passado, presente e futuro. "Conforme o acento seja colocado no passado, no futuro ou no presente, a ordem do tempo, com efeito, não é a mesma. O regime de historicidade não é uma realidade dada, mas um instrumento heurístico. Não tendo uma função denotativa, ela se aproxima da noção de tipo-ideal weberiano. ... O antigo regime de historicidade corresponde ao modelo da historia magistra vitae: ele se funda sobre o paralelo, faz apelo às lições da história e recorre à imitação. $\mathrm{O}$ passado não é (verdadeiramente) do passado, pois ele não foi ultrapassado” (HARTOG, François. Temps du monde, histoire, écriture de l'histoire. Texto da conferência proferida em 05 de outubro de 2005 no IFCH/UFRGS, cedido pelo autor).

${ }^{24}$ BARBOSA, Januário da Cunha. Discurso. Op. cit., p.14.

${ }^{25}$ CEZAR, Temístocles. Lição sobre a escrita da história. Historiografia e nação no Brasil do século XIX. Diálogos, Maringá/Paraná, v.8, p.12.

${ }^{26}$ BARBOSA. Op. cit., p.9.

27 GUIMARÃES, Manoel Luiz Salgado. Nação e Civilização nos Trópicos: o Instituto Histórico e Geográfico Brasileiro e o projeto de uma História Nacional. Estudos Históricos, Rio de Janeiro, n.1, p.16, 1988. Ver também MATTOS, Ilmar. O tempo saquarema. A formação do estado imperial. 5.ed. São Paulo: Editora Hucitec, 2004.

${ }^{28}$ BARBOSA. Op. cit., p.15. A idéia de uma história do Brasil “expurgada” dos erros e das lacunas das obras congêneres anteriormente produzidas aparece logo no início do discurso do primeiro secretário e é reiterada em inúmeras passagens de sua fala. Temístocles Cezar observa que este aspecto costuma ser negligenciado pelos estudiosos da historiografia brasileira. "Na verdade, a história feita no IHGB não foi sempre original; seus membros reconheciam a existência de produções que lhes eram anteriores, que eles revisavam e corrigiam. Esse processo de purificação é o primeiro passo em direção à transformação daquilo que antes era lido como história em fonte histórica, devendo servir de base à escrita da história da pátria” (CEZAR, Temístocles. L’écriture de l'histoire au Brésil au XIX ${ }^{\mathbf{e}}$ siècle. Essai sur une rhétorique de la nationalité. Le cas Varnhagen. Paris: EHESS, 2002, p.214. Tese de Doutorado).

29 BARBOSA. Op. cit., p.9.

30 SANCHEZ. Op. cit., p.60.

31 BARBOSA. Op. cit., p.14.

${ }^{32}$ É possível fazer uma aproximação entre o discurso de Cunha Barbosa e o programa historiográfico da Academia Real de História Portuguesa, criada em 1720. Íris Kantor destaca que, em seu objetivo de escrever a história das conquistas ultramarinas, os acadêmicos afirmavam a necessidade de registrar as ações gloriosas dos portugueses de todas as partes do Império para as gerações futuras, pois "nos feitos valorosos dos seus antepassados [estavam] os melhores exemplos do amor a pátria, do zelo e da fidelidade para se instruírem na obrigação de imitá-los ...” (Panegírico de Diogo Barbosa Machado. Apud KANTOR. Op. cit., p.57-58).

${ }^{33}$ BARBOSA. Op. cit., p.14-15.

34 Idem, p.15-16.

35 BARBOSA, Januário da Cunha. Lembrança do que devem procurar nas províncias os sócios do Instituto Histórico Brasileiro, para remeterem à Sociedade central do Rio de Janeiro. RIHGB, t.I, p.128130, 1839.

36 Sanchez observa que, embora não haja uma divisão rigorosa do material publicado, podem-se destacar dois grupos de textos que constituíram um espaço relativamente delimitado e constante no periódico: as atas (e demais papéis administrativos do Instituto) e as biografias. As atas das sessões ordinárias e assembléias do Instituto foram publicadas desde o primeiro tomo e, de modo geral, apareciam todos os trimestres e sempre situadas ao fim de cada número (SANCHEZ. Op. cit., p.105-106).

${ }^{37}$ Nos tomos referentes aos anos de 1853, 1854 e 1855, 1856, 1857, 1858(?) e 1859 não há seção de biografias. No Tomo XVIII, 1855, foram publicados Apontamentos sobre a vida do índio Guido Pokrane e sobre o francez Guido Marlière (oferecido pelo sócio Luiz Pedreira do Couto Ferraz), p.426-432; e Aditamento aos apontamentos para a biografia do índio Guido Pokrane, p.432-434.

${ }^{38}$ Ver BONNET, Jean-Claude. Les morts illustres,. Oraison funèbre, éloge académique, nécrologie. In: NORA, Pierre. Les lieux de mémoire II. La nation. Paris: Gallimard, 1986. p.222.

${ }^{39}$ Ata da $10^{\text {a }}$ Sessão em 20 de Abril de 1839. RIHGB, 1.ed., t. I,p.132, 1839. 
${ }^{40}$ Ata da $13^{\mathrm{a}}$ Sessão em $1^{0}$ de Junho de 1839. RIHGB, 1.ed., t.I, p.136-137, 1839.

${ }^{41}$ Em 1842, no Tomo IV da Revista, seria publicado o "Extracto dos Annaes do Rio de Janeiro" de autoria do conselheiro, no qual consta uma relação "das pessoas distinctas que ajudaram á fundação e edificação do Rio de Janeiro” (p.318-330). Além disso, na biografia de Frei Manoel de Santa Maria Itaparica, de autoria de Varnhagen, em uma nota de pé de página é feita uma referência a informações obtidas "na noticiosa collecção de Apontamentos biographicos sobre a vida de varios brasileiros illustres, que foi legada ao Instituto pelo seu falecido membro honorário o conselheiro Balthazar da Silva Lisboa ...” (RIHGB, t.X, p. 241, 1848).

${ }^{42}$ Em ata da $46^{\mathrm{a}}$ sessão em 31 de agosto de 1840, lê-se que "o Sr. Conselheiro Bento da Silva Lisboa fez leitura de um elogio histórico do seu fallecido tio o nosso sempre chorado consocio o Sr. Conselheiro Balthazar da Silva Lisboa. O Instituto ouviu com profunda dor a leitura deste elogio, e agradecendo ao nosso socio effetivo o seu interessante trabalho, determinou que ele fosse endereçado á Comissão de redacção, a fim de ser publicado no n.7 da Revista Trimensal” (RIHGB, t.II, p.413). Biographia do Conselheiro Balthazar da Silva Lisboa (RIHGB, 1'ed., t.II, 1840, p.383-391). No mesmo tomo também foi publicado um "elogio histórico" ao conselheiro, ver Elogio historico do fallecido membro honorario o conselheiro Balthazar da Silva Lisboa, recitado pelo Sargento-mór Pedro d'Alcantara Bellegarde, Orador do Instituto (t.II, suplemento, p.590-595).

${ }^{43}$ Ata da $173^{\mathrm{a}}$ sessão em 22 de julho de 1847 (RIHGB, t.IX, p.424, 1847).

${ }^{44}$ GUIMARÃES, Nação e civilização. Op. cit., p.9). O estatuto aprovado quando da fundação do IHGB previa que a admissão de sócios dar-se-ia fundamentalmente por meio das relações sociais, sem a exigência de produção intelectual na área da história ou da geografia. Somente a partir de 1841 em um artigo estatutário aditivo estabelecia-se que, para ser admitido sócio efetivo ou correspondente do Instituto, era necessário "ter offerecido ao mesmo Instituto, ou pelo menos publicado alguma producção litteraria, que possa servir de título para a admissão, ou ter feito alguma offerta de valor" (Ata da $77^{\mathrm{a}}$ sessão em 5 de dezembro de 1841, RIHGB, t.III, p.508, 1841;. Estatutos do Instituto Historico e Geographico Brazileiro, Rio de Janeiro: Typographia de F. de Paula Brito, 1851. p.4).

45 Foram eles: José Eloy Pessoa (1792-1841, sócio correspondente na Bahia); Henrique Julio de Wallenstein (1790-1843, de nacionalidade russa); Domingos J. Gonçalves de Magalhães (1811-1882, sócio efetivo); Joaquim Caetano da Silva (1810-1873).

${ }^{46}$ Sobre o elogio acadêmico, Bonnet afirma que o gênero se desenvolve na França no século XVIII, relacionando-se a um amplo processo de laicização em que a antiga laudatio funebris cede lugar à palavra cívica institucional fundada em uma nova forma de exemplaridade nitidamente temporal. Trata-se "não mais da graça que inspirava outrora o herói e o santo, mas do entusiasmo do gênio". O elogio impõe-se, então, como um novo gênero de discurso que preconiza a virtude e é dedicado "às qualidades e ações que mais contribuíram para o bem público e para a felicidade dos homens" (BONNET, Les morts illustres, op. cit., p.220).

${ }^{47}$ Art. 35, $2^{0}$ parágrafo. Estatutos do Instituto Historico e Geographico Brazileiro. Rio de Janeiro:

Typographia Universal de Laemmert \& C., 1890. Elogios fúnebres proferidos pelo orador também são incluídos nas atas das sessões.

${ }^{48}$ Ata da $63^{\mathrm{a}}$ sessão em 19 de maio de 1841. RIHGB, t.III, p.234.

${ }^{49}$ ROCHE, Daniel. Le siècle des Lumières em province. Academies et académiciens provinciaux, 1680-1789. Paris: EHESS, 1989 [1978].

${ }^{50}$ Relatorio lido no acto de solemnisar-se o $5^{\circ}$ anniversario do Instituto Histórico e Geográfico Brasileiro pelo Secretario Perpetuo o Cônego Januário da Cunha Barbosa. Quinta Sessão Publica Anniversaria do Instituto Historico Geographico Brasileiro no dia 10 de dezembro de 1843. RIHGB, Suplemento ao Tomo V, p.23-24. 1843.

${ }^{51}$ ENDERS, Armelle. O Plutarco Brazileiro. A produção dos vultos nacionais no segundo reinado. Estudos Históricos, Rio de Janeiro, 2000. p.43-44.

${ }^{52}$ Biographia dos Brasileiros distinctos por lettras, armas, virtudes, etc. José Fernandes Vieira (o Castrioto lusitano). RIHGB, t.V, p.82, 1843.

${ }^{53}$ Nesse caso, também se torna inevitável relacionar a nota com a própria biografia de seu autor. Nascido em Sorocaba, província de São Paulo, F. Adolfo de Varnhagen era filho de um alemão e de uma portuguesa, viveu sua juventude em Portugal, onde prestou serviços militares e foi promovido a oficial do exército português - o que tornou necessário um decreto de anistia do Imperador para que sua nacionalidade brasileira fosse reconhecida. LESSA, Clado R. de. Correspondência ativa de Francisco Adolfo de Varnhagen. Rio de Janeiro: INL, 1961. p.83-85.

${ }^{54}$ JANCSÓ, István. Independência, independências. In: JANCSÓ, István (org.). Independência: história e historiografia. São Paulo: Editora Hucitec/Fapesp, 2005. p.17-48. 
${ }^{55}$ MORAES SILVA, Antonio de. Diccionario de Lingua Portugueza recopilado de todos os impressos ate' o presente, por Antonio de Moraes e Silva. Offerecido ao muito alto, e muito poderoso Senhor D. João VI, Rei de Portugal, Brazil e Algarve \&c. Terceira edição, mais correcta e accrescentada de cinco para seis mil artigos, que levão este sinal * extrahidos dos Authores Classicos Portuguezes, com disvello e curiosidade. Lisboa: Typographia de M. P. de Lacerda, 1823. [1.ed. 1789; 2.ed. 1813].

56 REBELO, Luís de Sousa. A tradição clássica na literatura portuguesa. Lisboa: Horizonte Universitário, 1982. p.39. Curtius traça uma genealogia da tópica demonstrando a sua filiação ao topos sapientia et fortitudo dos heróis em Homero e Virgílio. A união entre virtudes letradas e guerreiras atingiria o máximo de sua expressão na literatura espanhola dos séculos XVI e XVII, com Garcilaso, Cervantes, Lope e Calderón - todos poetas e soldados, prestadores de serviços ao reino. Nesses autores, o tema das armas y letras, por vezes, sofre variações e aparece nos usos da fórmula pluma y espada (CURTIUS, E. R. Literatura européia e Idade Média Latina. Brasília: INL, 1979. p.177-187).

${ }^{57}$ REBELO. Op. cit., p.208.

${ }^{58}$ CAMÕES, Luís de. Os Lusíadas [Canto V, 96 a e 97 a estrofes]. In: Obra Completa. Rio de Janeiro: Aguilar Editora, 1963. p.136 [grifos meus]. Para outras variações no uso da tópica, ver Canto III, $13^{\mathrm{a}}$ e $14^{\mathrm{a}}$ estrofes.

${ }^{59}$ PÉCORA, Alcir. As artes e os feitos. In: Máquina de gêneros. São Paulo: Edusp, 2001, p.162.

${ }^{60}$ Idem, p.138.

${ }^{61}$ Sobre as aproximações entre a história e a poesia épica, ver YILMAZ, Levent. Como a História deveria ser escrita; ou deve mesmo ser escrita? Agora, Santa Cruz do Sul, v.11, n.1, jan.-jun.-2005. p.23-24.

${ }^{62}$ Importante lembrar que a fórmula reaparece nos tercetos de Camões, escritos sob encomenda para compor a dedicatória da História da província Santa Cruz que Pero de Magalhães de Gândavo publica em 1576: “... bem sabemos dos antigos/Heróis, e dos modernos, que provaram/De Belona os gravíssimos perigos,/Que também muitas vezes ajuntaram/Às armas eloqüência, porque as Musas/Mil capitães na guerra acompanharam;/Nunca Alexandre ou César nas confusas/Guerras deixaram o estudo um breve espaço,/Nem armas das ciências são escusas" (GÂNDAVO, Pero de Magalhães de. História da província Santa Cruz a que vulgarmente chamamos Brasil. Modernização do texto original de 1576 e notas de Sheila Moura Hue e Ronaldo Menegaz. Rio de Janeiro: Jorge Zahar Editor, 2004. p.31 [grifo meu]).

${ }^{63}$ REBELO. op. cit., p.42.

${ }^{64}$ GUIMARÃES. Nação e civilização, op. cit., p.6.

${ }^{65}$ CAMÕES, L. de. Lusíadas, X, 67. In: Biographia dos Brasileiros Distinctos por letras, armas, virtudes \&tc. Martim Affonso de Sousa. RIHGB, t.V, p. 248, 1843.

${ }^{66}$ ENDERS. Op. cit., p.59. Para o perfil socioprofissional dos sócios fundadores do IHGB, ver

GUIMARÃES. Debaixo da imediata proteção de Sua Majestade Imperial, op. cit., p.476-478.

${ }^{67}$ Biographia dos Brasileiros Distinctos por Lettras, Armas, Virtudes, \&tc. Clemente Pereira de Azeredo Coutinho. RIHGB, t.IV, p.88 [grifo meu]. As biografias dos irmãos Francisco de Lemos de Faria Pereira Coutinho e João Pereira Ramos de Azeredo, a primeira escrita por Varnhagen, e a outra, por J. da Cunha Barbosa, estão no Tomo II, 1840, p.388-394 e p.118-127, respectivamente. O terceiro irmão de Clemente Pereira, Ignácio de Andrade Souto Maior Rendon, também foi biografado por Varnhagen (ver t.V, p. 241248, 1843.

${ }^{68}$ ENDERS. Op. cit., p.51.

69 Discurso do Presidente Exm. Sr. Visconde de São Leopoldo. Quarta Sessão Publica Anniversaria do Instituto Historico e Geografico Brasileiro no dia 27 de novembro de 1842. RIHGB, Suplemento ao Tomo IV, p.2-3.

${ }^{70}$ Ata da $66^{\text {a }}$ sessão em 1 de julho de 1841 (Idem, p.349).

${ }^{71}$ Ata da $68^{\mathrm{a}}$ sessão em 12 de agosto de 1841 (Idem, p.360).

${ }^{72}$ Biographia dos Brasileiros Distinctos por lettras, armas, virtudes, etc. RIHGB, t.IV, p.377-378, 1842.

${ }^{73}$ Idem, p.378.

${ }^{74}$ BARBOSA. Op. cit., p.12.

${ }^{75}$ A palavra Bibliotheca não designa um espaço arquitetônico para a organização dos livros, mas um catálogo sobre outros livros. Como o extenso e descritivo título indica, trata-se de uma obra Histórica, Critica, e Chronologica, na qual se comprehende a noticia dos auctores portugueses, e das obras que compuzeram desde o tempo da promulgação da lei da Graça até o tempo presente. Em ordem alfabética por seus prenomes, mais de 5.000 figuras são apresentadas ao leitor mediante suas biografias e obras manuscritas ou impressas, desde o nascimento de Cristo até o tempo de seu autor (MACHADO, Diogo Barbosa. Bibliotheca Lusitana [recurso eletrônico]. Lisboa: Comissão Nacional para as Comemorações dos Descobrimentos Portugueses, 1998. 1 Cd-rom e folheto). Como assinala Ana Paula Sampaio Caldeira, todo um trabalho de pesquisa e coleta de documentos foi elaborado pelo abade enquanto 
montava a sua Bibliotheca Lusitana. Para compor esta obra, Barbosa Machado consultou autores que tentaram uma empresa semelhante e ainda pediu ajuda, por meio de correspondência, a outros eruditos, pedindo-lhes que mandassem informações sobre a vida e as produções de escritores portugueses (CALDEIRA, Ana Paula S. O colecionismo no século XVIII e o caso da Coleção Barbosa Machado, p.10. (artigo inédito cedido pela autora)). Sobre a coleção Barbosa Machado, ver também: MONTEIRO, R. B. Recortes de memória: reis e príncipes na coleção Barbosa Machado. In: SOIHET, Rachel; BICALHO, Maria Fernanda Baptista \& GOUVÊA, Maria de Fátima Silva. Culturas Políticas. Ensaios de história cultural, história política e ensino de história. Rio de Janeiro: Mauad, 2005. p.127-154.

${ }^{76}$ Sobre o método crítico e a ilustração ibérica, ver KANTOR. Op. cit., pp.69-87.

${ }^{77}$ MACHADO, D. B. Prólogo, op. cit.

${ }^{78}$ BELO, André. Da biblioteca ideal à biblioteca virtual. In: MACHADO, D. B. Op. cit.

${ }^{79}$ No contexto ibérico do século XVI, a forma de narrativa histórica que parece ser a mais próxima do panegírico seria a crônica, tal como a escrevia o português João de Barros (1496? -1570). No entanto, algumas distinções entre um gênero e outro devem ser consideradas: "a principal é a de que o tempo do enunciado da crônica é o passado, isto é, ela se refere ao que se ouviu a respeito das ações de alguém e, por isso, de acordo com João de Barros, existe basicamente em relação com a faculdade da memória do autor”. Já o recurso fundamental do panegírico “é a representação que coloca diante dos olhos do leitor, por meio de uma composição assentada na vivacidade do que se narra, de tal modo que se imagina testemunhado pela vista, no exato presente da leitura” (PÉCORA, Alcir. A história como colheita rústica de excelências. In: SCHWARTZ, S. e PÉCORA, A. (org.). As excelências do governador: o panegírico fúnebre a D. Afonso Furtado, de Juan Lopes Siera (Bahia, 1676). São Paulo: Cia. das Letras, 2002. p.48-49.

80 Idem, p.48.

${ }^{81}$ CALDEIRA. Op. cit., p.10.

${ }^{82}$ Carta ao Cônego Januário da Cunha Barbosa [8 de julho de 1841]. In: LESSA, Correspondência ativa, op. cit., p.63. Varnhagen foi admitido sócio do IHGB em 20 de janeiro de 1840.

${ }^{83}$ É Arnaldo Momigliano quem chama a atenção para a necessidade de se examinarem, além das ligações entre história e biografia, as relações entre biografia e erudição. "Os gregos distinguiam entre história e erudição, entre o que chamavam historia e o que designavam pelos temos menos claros e mais ambíguos de archeologia ou philologia, que os romanos traduziram por antiquitates. A distinção fundamental entre esses dois tipos de textos era a seguinte: a história trataria principalmente dos acontecimentos políticos e militares e seguiria uma ordem cronológica; a erudição, por sua vez, se ocuparia de todo o resto e, à ordem cronológica, preferiria uma exposição sistemática. ... Sabe-se que na época helenística, a biografia evoluiu paralelamente aos comentários e exposições filológicas ..., constata-se uma ligação estreita entre a biografia e a filologia. Mas o dado mais importante a ser considerado está em que as biografias antigas não seguiam necessariamente uma ordem cronológica, ... A biografia antiga apresenta, de fato, uma característica que [Fiedrich] Leo nos ensinou a identificar em Suetônio. À primeira vista, este tipo de biografia oferece semelhanças formais com as estrutura das obras de erudição” (MOMIGLIANO, Les origines de la biographie, op. cit., p.26-27). A questão também é tratada em: O surgimento da pesquisa antiquária. In: As raízes clássicas da historiografia moderna. Bauru/SP: Edusc, 2004. p.95-106.

${ }^{84}$ Ata da $98^{\mathrm{a}}$ Sessão em 19 de janeiro de 1843. RIHGB, t.V, p.94-95, 1843. As biografias de Francisco Lemos e de João Pereira Ramos, de autoria de Varnhagen e de J. da Cunha Barbosa respectivamente, foram publicadas no Tomo II da Revista.

${ }^{85}$ ENDERS. Op. cit., p.42.

${ }^{86}$ Carta ao Imperador D. Pedro II [14/07/1857]. LESSA Op. cit., p.246.

${ }^{87}$ Idem. 